\title{
Employers' Views on Desirable Theoretical Knowledge Qualities of Newly Qualified Social Workers: A Qualitative Exploration
}

Citation for published version (APA):

Van Bommel, M., Kwakman, K., \& Boshuizen, E. (2014). Employers' Views on Desirable Theoretical Knowledge Qualities of Newly Qualified Social Workers: A Qualitative Exploration. British Journal of Social Work, 45(4), 1330-1348. https://doi.org/10.1093/bjsw/bcu006

DOI:

10.1093/bjsw/bcu006

Document status and date:

Published: 12/02/2014

Document Version:

Other version

Please check the document version of this publication:

- A submitted manuscript is the version of the article upon submission and before peer-review. There can be important differences between the submitted version and the official published version of record. People interested in the research are advised to contact the author for the final version of the publication, or visit the DOI to the publisher's website.

- The final author version and the galley proof are versions of the publication after peer review.

- The final published version features the final layout of the paper including the volume, issue and page numbers.

Link to publication

\section{General rights}

Copyright and moral rights for the publications made accessible in the public portal are retained by the authors and/or other copyright owners and it is a condition of accessing publications that users recognise and abide by the legal requirements associated with these rights.

- Users may download and print one copy of any publication from the public portal for the purpose of private study or research.

- You may not further distribute the material or use it for any profit-making activity or commercial gain

- You may freely distribute the URL identifying the publication in the public portal.

If the publication is distributed under the terms of Article 25fa of the Dutch Copyright Act, indicated by the "Taverne" license above, please follow below link for the End User Agreement:

https://www.ou.nl/taverne-agreement

Take down policy

If you believe that this document breaches copyright please contact us at:

pure-support@ou.nl

providing details and we will investigate your claim.

Downloaded from https://research.ou.nl/ on date: 26 Apr. 2023 
Employers' views on desirable theoretical knowledge qualities of newly qualified social workers: A qualitative exploration.

Van Bommel, M., Kwakman, K., \& Boshuizen, H. P. A.

This study is a qualitative exploration of Dutch social work employers' views on desirable theoretical knowledge qualities of recently qualified bachelors of social work and how these qualities are weighed in hiring decisions. Participants $(n=18)$ from sixteen social work organisations were interviewed about descriptions of four personas, fictitious but life-like job applicants. These personas were created based on outcomes of earlier investigations revealing patterns of different knowledge qualities and personal attributes such as learning motivation, epistemological views, language use, personal and professional identity.

Qualitative analysis was performed by pre-structured and open coding. Results showed that employers see well-developed theoretical knowledge as necessary for addressing current requirements and ambitions in Dutch social work practice. Demands on new entrants' knowledge qualities have been raised accordingly. However, in hiring decisions, applicants' personal attributes pertaining to skills and attitude appeared more decisive than knowledge qualities. Employers assumed that personal attributes are difficult to alter, while knowledge can be learned more easily. Furthermore, excellent theoretical knowledge qualities and ambitions, though highly valued, were associated with fewer abilities for and lasting interest in daily work with clients.

Link doi:10.1093/bjsw/bcu006 